\title{
PERBEDAAN LAMA RAWAT INAP PADA PENDERITA DIARE AKUT BAYI YANG DITERAPI DENGAN ZINK DIBANDINGKAN ZINK DAN CAIRAN REHIDRASI ORAL DI RSUP SANGLAH
}

\section{(DIFFERENCE OF THE LENGTH OF THE HOSPITALIZATION OF INFANTS WITH ACUTE DIARRHEA TREATED WITH ZINC COMPARED TO TREATED WITH ZINC AND ORAL REHYDRATION SOLUTION IN RSUP SANGLAH)}

\author{
NI NYOMAN WAHYU UDAYANI ${ }^{1 *}$
}

${ }^{1}$ Akademi Farmasi Saraswati Denpasar, Jalan Kamboja no. 11A, Denpasar, Bali

\begin{abstract}
Abstrak: Diare saat ini masih menjadi salah satu masalah kesehatan, jutaan kasus dilaporkan setiap tahun dan diperkirakan sekitar 4-5 juta orang meninggal karena diare akut. Angka kejadian diare akut di sebagian besar wilayah Indonesia hingga saat ini masih tinggi termasuk angka morbiditas dan mortalitasnya. Berdasarkan riset hasil kesehatan dasar (Riset Kesehatan Dasar 2007) yang dilakukan oleh Kementrian Kesehatan pada tahun 2007, diare akut merupakan penyebab kematian bayi (31,4\%). Menurut Korompis dkk (2013) penggunaan suplemen zink pada penderita diare akut sebesar 69\% serta penggunaan ORS (Oral Rehydration Solution) dan zink sebesar $15,85 \%$. Tujuan dari penelitian ini untuk mengetahui perbedaan lama rawat inap pada penderita diare akut bayi yang diterapi dengan zink dibandingkan zink dan cairan rehidrasi oral di RSUP Sanglah Denpasar. Penelitian ini merupakan penelitian non eksperimental dengan menggunakan rancangan deskriptif analitik. Penelitian ini menggunakan data penggunaan obat diare akut bayi bulan Januari-Desember 2013 yang bersifat retrospektif, yang diambil pada unit catatan rekam medik di RSUP Sanglah Denpasar. Dari 30 sampel diare akut bayi yang dirawat inap di RSUP Sanglah Denpasar mayoritas berjenis kelamin laki-laki. Rata-rata lama rawat inap penderita diare akut bayi yang diterapi dengan zink 3,07 hari dan terapi dengan zink dan cairan rehidrasi oral 3,20 hari. Hasil penelitian menunjukkan bahwa tidak adanya perbedaan lama rawat inap secara signifikan menurut statistik antara penderita diare akut bayi yang diterapi dengan zink dan diterapi dengan zink dan cairan rehidrasi oral.
\end{abstract}

Kata kunci: diare akut, bayi, zink, cairan rehidrasi oral.

Abstract: Currently diarrhea is still become one of the health problems, millions of cases are reported each year and an estimated 4-5 million people died of acute diarrhea. The incidence of acute diarrhea in most parts of Indonesia is still high, including morbidity and mortality. Based on the results of basic medical research (Basic Health Research 2007) conducted by the Ministry of Health in 2007, acute diarrhea is the cause of infant mortality (31.4\%). According to Korompis et al (2013) use of zinc supplements in patients with acute diarrhea by $69 \%$ and the use of ORS (Oral Rehydration Solution) and zinc by $15.85 \%$. The purpose of this study was to determine differences in length of stay in patients with acute diarrhea infants treated with zinc than zinc and oral rehydration solution in Sanglah Hospital. This study is a non-experimental study using analytic descriptive design. This study uses data from the drug used by diarrhea baby in months from January to December 2013, which is retrospective, which was taken at the unit medical record in the hospital Sanglah. Of the 30 samples of infant acute diarrhea that hospitalized at Sanglah Hospital, the majority of the sex was male. The average length of hospitalization with acute diarrhea infants treated with zinc was 3.07 days, and the therapy with zinc and oral rehydration solution was 3.20 days. The results showed that there is no significant difference in length of stay according to statistical analysis between infants with acute diarrhea that treated with zinc and treated with zinc and oral rehydration solution.

Keywords: acute diarrhea, infants, zinc, oral rehydration solution.

\section{PENDAHULUAN}

Diare saat ini masih menjadi salah satu masalah kesehatan, jutaan kasus dilaporkan setiap tahun dan diperkirakan sekitar 4-5 juta orang meninggal karena diare akut (Adyanastri, 2012). Angka kejadian diare akut di sebagian besar wilayah Indonesia hingga saat ini masih tinggi

\footnotetext{
* Penulis korespondensi, Hp. 081934325857

e-mail : udayani.wahyu@yahoo.com
} 
termasuk angka morbiditas dan mortalitasnya. Penyebaran penyakit diare akut ini juga tersebar ke semua wilayah di Indonesia dengan penderita terbanyak adalah bayi dan balita. Berdasarkan riset hasil kesehatan dasar (Riset Kesehatan Dasar 2007) yang dilakukan oleh Kementrian Kesehatan pada tahun 2007, diare akut merupakan penyebab kematian bayi $(31,4 \%)$ dan balita $(25,2 \%)$ (Korompis dkk, 2013). Menurut World Gastroenterology Organisation Global Guidelines (2012), setiap anak di bawah usia 5 tahun mengalami rata-rata tiga episode tahunan diare akut. Secara global dalam kelompok usia ini, diare akut adalah penyebab utama kematian (setelah pneumonia), khususnya selama bayi.

Penggunaan obat pada penderita diare akut harus berdasarkan pertimbangan klinis. Karena apabila obat-obat tersebut diberikan secara tidak tepat maka akan menyebabkan penyakit diare akut tidak bisa sembuh bahkan akan memperparah (Korompis dkk, 2013). Sampai saat ini diare akut masih merupakan penyakit yang sering menyebabkan dehidrasi. Dehidrasi merupakan salah satu komplikasi penyakit diare akut yang dapat menyebabkan kematian. Untuk menanggulangi dehidrasi pada diare akut dapat diberikan oralit (Riskesdas, 2007). Menurut Korompis dkk (2013), penggunaan oralit pada penderita diare akut sebesar $89,28 \%$. Dalam penatalaksaan pengobatan diare akut, zink mampu mengurangi durasi episode diare hingga sebesar 25\%. Beberapa penelitian menunjukkan pemberian zink mampu menurunkan volume dan frekuensi tinja rata-rata sebesar $30 \%$. Zink juga menurunkan durasi dan keparahan pada diare persisten (Pratama, 2009). Menurut Korompis dkk (2013) penggunaan suplemen zink pada penderita diare akut sebesar $69 \%$.

Sejak tahun 2004, WHO dan UNICEF menandatangani kebijakan bersama dalam hal pengobatan diare yaitu pemberian oralit dan zink selama 10-14 hari. Hal ini didasarkan pada penelitian selama 20 tahun (1980-2003) yang menunjukkan bahwa pengobatan diare dengan pemberian oralit disertai zink lebih efektif dan terbukti menurunkan angka kematian akibat diare pada anak-anak sampai 40\% (Depkes RI, 2011). Menurut Korompis dkk (2013) penggunaan ORS dan zink pada penderita diare akut sebesar $15,85 \%$.

Rumah Sakit Umum Pusat (RSUP) Sanglah Denpasar merupakan salah satu rumah sakit terbesar serta menjadi rumah sakit rujukan pertama di Bali. Sehingga hampir seluruh masyarakat di wilayah Denpasar dan sekitarnya yang sakit dirawat di rumah sakit ini. Rumah Sakit Umum Pusat (RSUP) Sanglah Denpasar merupakan salah satu rumah sakit yang menggunakan terapi kombinasi dan dengan jumlah pasien diare akut yang banyak. Penelitian ini bertujuan untuk mengetahui perbedaan lama rawat inap pada penderita diare akut bayi yang diterapi dengan zink dibandingkan zink dan cairan rehidrasi oral di RSUP Sanglah Denpasar.

\section{METODE PENELITIAN}

Rancangan Penelitian. Penelitian ini merupakan penelitian non eksperimental dengan menggunakan rancangan deskriptif analitik. Penelitian ini menggunakan data rekam medis bersifat retrospektif yang diambil pada unit catatan rekam medis di RSUP Sanglah Denpasar.

Lokasi dan Waktu Penelitian. Penelitian dilakukan di ruang rawat inap Jempiring dan rekam medis RSUP Sanglah Denpasar dengan surat ijin dan pengambilan data terlampir (rekam medis). Waktu penelitian dilakukan pada bulan November 2013-Mei 2014 dengan mengambil data rekam medis pasien diare akut bayi pada bulan JanuariDesember 2013.

Populasi dan Sampel. Sebagai populasi penelitian adalah semua pasien bayi rawat inap di RSUP Sanglah yang menderita diare akut yang diterapi dengan zink serta zink dan cairan rehidrasi oral selama bulan Januari-Desember 2013. Sampel penelitian adalah pasien bayi rawat inap di RSUP Sanglah yang menderita diare akut yang diterapi dengan zink serta zink dan cairan rehidrasi oral yang memenuhi kriteria inklusi dan tidak memenuhi kriteria eksklusi selama bulan Januari-Desember 2013.

Kriteria Inklusi. Pasien bayi umur 1 bulan-2 tahun; Pasien bayi yang menderita penyakit diare akut yang dirawat inap dengan pemakaian zink serta zink dan cairan rehidrasi oral.

Kriteria Eksklusi. Pasien bayi dengan data tidak lengkap; Pasien bayi dengan penyakit penyerta; Pasien bayi pulang paksa; Pasien bayi meninggal.

Definisi Operasional. Definisi operasional dalam penelitian ini meliputi:

1. Diare akut adalah buang air besar dengan konsistensi lembek atau cair yang berlangsung kurang dari 14 hari dengan frekuensi lebih dari 3 kali perhari.

2. Pasien adalah seorang dengan diagnosa diare akut usia 1 bulan sampai 2 tahun yang dirawat inap atau menerima perawatan medis di ruang Jempiring RSUP Sanglah Denpasar yang mendapat terapi obat zink, kombinasi zink dan cairan rehidrasi oral. 
3. Rekam medis adalah catatan atau berkas yang berisikan sebuah perekaman mengenai hasil pengobatan pasien. Catatan tersebut berupa identitas pasien seperti nama, umur, jenis kelamin, keluhan, data laboratorium, obat, dosis, dan lama rawat inap.

4. Lama rawat inap adalah rentang atau periode waktu sejak pasien diterima masuk ke rumah sakit hingga berakhirnya proses pengobatan dan pasien dinyatakan dapat pulang.

5. Penyakit penyerta adalah penyakit yang tidak termasuk dalam gejala-gejala diare akut seperti batuk.

Cara pengumpulan data. Cara pengumpulan data pada penelitian ini dilakukan menggunakan data sekunder dengan cara melakukan pembacaan pada rekam medis pasien di RSUP Sanglah Denpasar. Awalnya dicari jumlah kasus diare akut pada bayi dari bulan Januari-Desember 2013 secara manual dengan melihat buku registrasi di ruang Jempiring dan mencatat nomor rekam medis kemudian nomor rekam medis tersebut dibawa ke ruangan rekam medis untuk dicari buku rekam medis pasien. Selanjutnya dilakukan pemilihan sampel yang sesuai dengan kriteria inklusi dan eksklusi. Data yang didapatkan kemudian dimasukkan ke dalam tabel yang meliputi nama, umur, jenis kelamin, keluhan, data laboratorium, obat, dosis, dan lama rawat inap.

Analisa Data. Analisa data pada penelitian ini dilakukan menggunakan deskriptif analitik dengan program SPSS 16.0. Data disajikan dalam bentuk tabel untuk melihat perbedaan lama rawat inap pada penderita diare akut bayi yang diterapi dengan zink dibandingkan zink dan cairan rehidrasi oral di RSUP Sanglah Denpasar periode Januari-Desember 2013.

\section{HASIL DAN PEMBAHASAN}

Dari data yang diperoleh diketahui populasi pasien yang menggunakan zink serta zink dan cairan rehidrasi oral sebesar 32 pasien. Setelah melalui proses pemilihan menggunakan kriteria inklusi dan eksklusi, sampel yang diambil sebesar 30 pasien.

Karakteristik Pasien Berdasarkan Jenis Kelamin. Karakteristik pasien berdasarkan lama rawat inap pada pasien diare akut di RSUP Sanglah Denpasar dapat dilihat pada tabel berikut:

Tabel 1. Karakteristik pasien berdasarkan jenis kelamin

\begin{tabular}{ccccc}
\hline \multirow{2}{*}{ Jenis kelamin } & \multicolumn{2}{c}{ Zink } & \multicolumn{2}{c}{ Zink dan Cairan Rehidrasi } \\
& \multicolumn{2}{c}{ Oral } \\
\cline { 2 - 5 } & $\begin{array}{c}\text { Jumlah } \\
\text { (orang) }\end{array}$ & $\begin{array}{c}\text { Persentase } \\
(\boldsymbol{\%})\end{array}$ & $\begin{array}{c}\text { Jumlah } \\
(\text { orang) }\end{array}$ & $\begin{array}{c}\text { Persentase } \\
(\%)\end{array}$ \\
\cline { 2 - 5 } Laki-laki & 11 & 73 & 11 & 73 \\
Perempuan & 4 & 27 & 4 & 27 \\
Total & 15 & 100 & 15 & 100 \\
\hline
\end{tabular}

\section{Klasifikasi Pasien Berdasarkan Lama Rawat}

Inap. Klasifikasi pasien berdasarkan lama rawat inap pada pasien diare akut di RSUP Sanglah Denpasar ditunjukkan pada tabel 4.2. Dari hasil analisis statistik pengujian sebaran data dengan mengetahui nilai standar skewness didapatkan hasil bahwa data tersebut terdistribusi normal dengan nilai 0,12 dan $-0,11$ dimana nilainya antara -2 sampai 2 (data terlampir). Selanjutnya menggunakan Independent Samples T-Test dengan nilai Sig $F=0,766$ dimana Sig $F>0,05$ (data terlampir). Hal ini menunjukkan tidak ada perbedaan lama rawat inap antara penderita diare akut bayi yang diterapi dengan zink dan penderita diare akut bayi yang diterapi dengan zink dan cairan rehidrasi oral.
Tabel 2. Klasifikasi pasien berdasarkan lama rawat inap

\begin{tabular}{ccc}
\hline No. & Zink (hari) & $\begin{array}{c}\text { Zink dan Cairan Rehidrasi } \\
\text { Oral (hari) }\end{array}$ \\
\hline $\mathbf{1 .}$ & 4 & 4 \\
$\mathbf{2 .}$ & 5 & 5 \\
$\mathbf{3 .}$ & 2 & 3 \\
$\mathbf{4 .}$ & 1 & 3 \\
$\mathbf{5 .}$ & 2 & 4 \\
$\mathbf{6 .}$ & 5 & 2 \\
$\mathbf{7 .}$ & 3 & 3 \\
$\mathbf{8 .}$ & 4 & 3 \\
$\mathbf{9 .}$ & 3 & 3 \\
$\mathbf{1 0 .}$ & 3 & 5 \\
$\mathbf{1 1 .}$ & 1 & 1 \\
$\mathbf{1 2 .}$ & 3 & 3 \\
$\mathbf{1 3 .}$ & 3 & 3 \\
$\mathbf{1 4 .}$ & 5 & 4 \\
$\mathbf{1 5 .}$ & 2 & 2 \\
Rata-rata & $\mathbf{3 , 0 7}$ & $\mathbf{3 , 2 0}$ \\
\hline
\end{tabular}

Berdasarkan hasil penelitian jumlah pasien diare akut lebih banyak dari pada diare kronis. Hal ini sesuai dengan (Suraatmaja, 2007 dalam Pratama, 2009) yang menyebutkan bahwa 70-80\% 
kasus diare pada balita adalah diare akut. Data morbiditas dan mortalitas di Sulawesi Tengah tahun 2012 juga menunjukkan bahwa diare akut menempati urutan pertama yaitu sebanyak 576 kasus. Tingginya kasus diare akut ini disebabkan oleh rotavirus (40-60\%) (Depkes RI, 2005 dalam Adyanastri, 2012). Di negara berkembang rotavirus merupakan virus usus patogen yang penting dan menduduki urutan pertama sebagai penyebab diare akut pada anak dengan persentase kasus bervariasi antara 15-20\%. Di Indonesia dilaporkan proporsi diare rotavirus sekitar 30-40\%. Sekitar sepertiga anak umur kurang dari 2 tahun pernah mengalami episode diare karena rotavirus, sebagian besar $(58,9 \%)$ kasus memerlukan perawatan di rumah sakit dan sering menjadi penyebab utama dari malnutrisi (Santoso dkk, 2005).

Berdasarkan tabel 4.1 jumlah penderita diare akut berjenis kelamin laki-laki pada masingmasing kelompok terapi yaitu 11 orang $(73 \%)$ lebih banyak dari pada perempuan yaitu 4 orang (27\%). Baik negara maju maupun berkembang, laki-laki mempunyai tingkat kematian lebih tinggi dari perempuan. Perkiraan kematian bayi dan anak hasil survei dan sensus di Indonesia mendukung hal tersebut. Balita dengan jenis kelamin laki-laki berisiko mengalami 1,42 kali diare dibandingkan dengan balita perempuan. Sedangkan menurut Harianto 2004 balita laki-laki berisiko mengalami diare 1,12 kali dibandingkan dengan balita perempuan. (Giyantini T, 2000 dan Harianto TM, 2004 dalam Pratama 2009).

Tabel 4.2 menunjukkan bahwa pasien bayi yang diterapi dengan zink memberikan waktu penyembuhan yaitu rata-rata rawat inap 3,07 hari sedangkan pasien bayi yang diterapi dengan kombinasi zink dan cairan rehidrasi oral dengan rata-rata rawat inap 3,20 hari. Zink merupakan salah satu zat gizi mikro yang penting untuk kesehatan dan pertumbuhan anak. Zink yang ada dalam tubuh akan menurun dalam jumlah besar ketika anak mengalami diare. Untuk menggantikan zink yang hilang selama diare, anak dapat diberikan zink yang akan membantu penyembuhan diare serta menjaga agar anak tetap sehat. Zink sebagai obat pada diare memberikan manfaat diantaranya, $20 \%$ lebih cepat sembuh jika anak diare diberi zink (penelitian di India), 20\% risiko diare lebih dari 7 hari berkurang, 18\%-59\% mengurangi jumlah tinja, dan mengurangi risiko diare berikutnya 2-3 bulan ke depan. Zink dan pengobatan pada diare akut dapat mengurangi lama diare hingga $25 \%$ (Depkes RI, 2011). Sejak tahun 2004, WHO dan UNICEF menandatangani kebijakan bersama dalam hal pengobatan diare yaitu pemberian oralit dan zink selama 10-14 hari. Hal ini didasarkan pada penelitian selama 20 tahun (1980-2003) yang menunjukkan bahwa pengobatan diare dengan pemberian oralit disertai zink lebih efektif dan terbukti menurunkan angka kematian akibat diare pada anak-anak sampai 40\% (Depkes RI, 2011).

Berdasarkan penelitian yang dilakukan, pengobatan tambahan dengan oralit tidak berpengaruh terhadap lama rawat inap. Oralit lebih cenderung untuk mengatasi dehidrasi yang terjadi pada penderita diare. Menurut Depkes RI Dirjen POM (2007), oralit tidak menghentikan diare, tetapi menggantikan cairan tubuh yang hilang bersama tinja. Dengan menggantikan cairan tubuh tersebut, terjadinya dehidrasi dapat dihindarkan. Renalyte ${ }^{\circledR}$ merupakan cairan rehidrasi oral dengan osmolaritas rendah seperti oralit baru. Menurut World Gastroenterology Organisation Global Guidelines (2012), oralit baru dengan osmolaritas rendah direkomendasikan oleh WHO dan UNICEF dengan mengurangi konsentrasi sodium dan glukosa yang dapat mengurangi muntah, mengurangi keluaran feses, memperkecil peluang terjadinya hipernatremia dan mengurangi kebutuhan infus intravena dibandingkan dengan cairan rehidrasi oral standar. Menurut Riandari dan Sri (2011), faktor-faktor lain yang dapat mempengaruhi lama rawat inap pada diare akut antara lain faktor status gizi, pemberian ASI, dan faktor kekebalan tubuh.

Dari hasil analisis statistik pengujian sebaran data dengan mengetahui nilai standar skewness didapatkan hasil bahwa data tersebut terdistribusi normal dengan nilai 0,12 dan $-0,11$ dimana nilainya antara -2 sampai 2 . Selanjutnya menggunakan Independent Samples T-Test dengan nilai Sig $F=0,766$ dimana Sig $F>0,05$ (tabel terlampir). Hal ini menunjukkan tidak ada perbedaan lama rawat inap antara penderita diare akut bayi yang diterapi dengan zink dan penderita diare akut bayi yang diterapi dengan zink dan cairan rehdrasi oral.

\section{SIMPULAN}

Rata-rata lama rawat inap pasien diare akut bayi yang diterapi dengan zink yaitu 3,07 hari sedangkan zink dan cairan rehidrasi oral yaitu 3,20 hari. Hasil penelitian menunjukkan bahwa tidak adanya perbedaan lama rawat inap secara signifikan menurut statistik antara penderita diare akut bayi yang diterapi dengan zink dan diterapi dengan zink dan cairan rehidrasi oral. 


\section{DAFTAR PUSTAKA}

Anonim, 2007, ISO Indonesia, Volume 42, Jakarta: Ikatan Sarjana Farmasi Indonesia, 175-176.

Anonim, 2013, MIMS Petunjuk Konsultasi, Edisi 12, Jakarta: Buana Ilmu Populer.

Adyanastri F, 2012, Etiologi dan Gambaran Klinis Diare Akut di RSUP Dr Kariadi Semarang, Semarang: Fakultas Kedokteran Universitas Diponegoro, (online), (http://eprints.undip.ac.id/37538/1/Festy G 2A008082_Lap_kti.pdf diakses 12 Juni 2014)

Aslam M, Chik KT, Adji P, 2002, Farmasi Klinis, Jakarta: PT Elex Media Komputindo, 191192.

Badan Penelitian dan Pengembangan Kesehatan Depkes RI, 2008, Riset Kesehatan Dasar (Rikesdas) 2007, (online), (http://fisiopoltekesolo.ac.id/fisioterapi/images/stories/l aporanNasional.pdf diakses 23 Februari $\underline{2014)}$

Departemen Kesehatan RI Direktorat Jenderal POM, 2007, Kompendia Obat Bebas, (online),

(http://www2.pom.go.id/public/publikasi/ko mpendia/berkas pdf/saluran\%20cerna.pdf diakses 3 Mei 2014)

Departemen Kesehatan RI Dirjen Pengendalian Penyakit dan Penyehatan Lingkungan, 2011, Buku Saku Petugas Kesehatan Lintas Diare, (online,)(https://agus34drajat.files.wordpres s.com/2010/10/buku-saku-lintas-diareedisi-2011.pdf diakses 22 April 2014)

Departemen Kesehatan RI Dirjen Pengendalian Penyakit dan Penyehatan Lingkungan, 2011, Panduan Sosialisasi Tatalaksana Diare Balita (online), (https://agus34drajat.files.wordpress.com/2 010/10/buku-panduan-sosialisasi-tatalaksana-diare-balita-2011.pdf diakses 22 April 2014)

Dibya IGN, 2008, Modul Ilmu Kesehatan Masyarakat (IKM) Kelas X, 37.

Hannif, Nenny SM, Susy K, 2011, Faktor Risiko Diare Akut pada Balita, Berita Kedokteran Masyarakat Vol. 27, No. 1, (online), (http://www.jurnal.ugm.ac.id/bkm/article/vi ew/3413/2961 diakses 5 Juli 2014)

Korompis F, Heedy T, Lily RG, 2013, Studi Penggunaan Obat pada Penderita Diare Akut di Instalasi Rawat Inap Blu RSUP Prof. Dr. R. D. Kandou Manado Periode Januari - Juni 2011, (online), (http://download.portalgaruda.org/article.ph $\mathrm{p}$ ?article $=15415 \& \mathrm{val}=1015 \&$ title diakses 4 Maret 2014)

Mansjoer A, Kaspuji T, Rakhmi S, Wahyu IW, Wiwiek S, 1999, Kapita Selekta Kedokteran, Edisi ketiga Jilid 1, Jakarta: Media Aesculapius, 500.

Mansjoer A, Suprohaita, Wahyu IW, 2000, Kapita Selekta Kedokteran, Edisi ketiga Jilid 2, Jakarta: Media Aesculapius, 470.

Munos MK, Christa LFW, Robert EB, 2010, The Effect of Oral Rehydration Solution and Recommended Home Fluids on Diarrhoea Mortality, (online), (http://www.ncbi.nlm.nih.gov/pmc/articles/ PMC2845864/ diakses 25 Maret 2014)

Musliha, 2010, Keperawatan Gawat Darurat, Yogyakarta: Nuha Medika, 162.

Pratama HA, 2009, Prevalensi Diare Akut pada Balita di Wilayah Kecamatan Ciputat Bulan September Tahun 2009, (online), (http://perpus.fkik.uinjkt.ac.id/file digital/S KRIPSI\%20Harry\%20Agung\%20_106103 003447,\%20FK\%20UIN\%202006.pdf diakses 17 Mei 2014)

Riandari F, Sri PM, 2011, Perbedaan Lama Rawat Inap Balita Diare Akut dengan Probiotik dan Tanpa Ptobiotik, (online), (http://portalgaruda.org/download_article.p hp diakses 15 Agustus 2014)

Santoso NB, Aulia AH, Sanarto S, 2005, Diare Rotavirus pada Anak Dibawah Usia 3 Tahun yang Dirawat di RSU Dr. Saiful Anwar Malang Tahun 2005, (online), (http://www.jkb.ub.ac.id/index.php/jkb/artic le/view/208 diakses 8 Maret 2014)

Saryono, 2011, Metodologi Penelitian Kesehatan, Jogjakarta: Mitra Cendika Press, 61,63. 
Soenarto Y, M Jufrie, 2007, Tatalaksana Diare pada Anak, Medan, 6.

Widjaja MC, 2002, Mengatasi Diare dan Keracunan Pada Balita, Jakarta: Kawan Pustaka, 38.

Wijoyo Y, 2013, Diare Pahami Penyakit \& Obatnya, Yogyakarta: PT Citra Aji Parama, 10.

World Gastroenterology Organization, 2008, Acute Diarrhea

(online), (http://www.worldgastroenterology.org/ass ets/downloads/en/pdf/guidelines/01_acute diarrhea.pdf diakses 2 Maret 2014)

World Gastroenterology Organization Global Guidelines, 2012, Acute Diarrhea in Adults and Children: A Global Perspective, (online),

(http://www.worldgastroenterology.org/ass ets/export/userfiles/Acute\%20Diarrhea lon g_FINAL_120604.pdf diakses 2 Maret 2014) 